\title{
Iridium-Catalyzed Hydrogen Production from Hydrosilanes and Water
}

\author{
Karin Garcés, ${ }^{[\mathrm{a}]}$ Francisco J. Fernández-Alvarez, ${ }^{[\mathrm{ad}]}$ Víctor Polo, ${ }^{[\mathrm{b}]}$ \\ Ralte Lalrempuia, ${ }^{[a]}$ Jesús J. Pérez-Torrente, ${ }^{[a]}$ and Luis A. Oro* ${ }^{[a]}$ \\ Dedication ((optional))
}

The iridium(III) complex $\left[\mathrm{Ir}(\mathrm{H})\left(\mathrm{CF}_{3} \mathrm{SO}_{3}\right)(\mathrm{NSiN})(\mathrm{coe})\right] \quad(\mathrm{NSiN}=$ bis(pyridine-2-yloxy)methylsilyl fac-coordinated) has proven to be an effective catalyst precursor for hydrogen production from the hydrolysis of hydrosilanes at room temperature. The reaction performance depends both on the silane nature and the solvent. Interestingly, high TOF values of around $10^{5} \mathrm{~h}^{-1}$ were obtained using
$\mathrm{Et}_{2} \mathrm{SiH}_{2}$ or $\left(\mathrm{Me}_{2} \mathrm{HSi}\right)_{2} \mathrm{O}$ as hydrogen sources and THF as solvent. Moreover a mechanistic insight of this iridium-catalyzed hydrogen generation process, based on both theoretical calculations and NMR studies, is reported. The overall catalytic cycle can be view as a two stages process involving i) the water promoted $\mathrm{Si}-\mathrm{H}$ bond activation which is followed by ii) the water splitting via a proton transfer.

\section{Introduction}

Development of new technologies that allow hydrogen storage with the highest possible volumetric energy density is considered as one of the challenges to overcome for the implementation of the hydrogen economy. ${ }^{[1]}$ Storing of renewable energy in chemical bonds for producing hydrogen on demand is emerging as a promising methodology for sustainable hydrogen storage/release. Thus, various substances as for instance ammonia and related chemicals, ${ }^{[2]}$ organosilanes, ${ }^{[3]}$ formic acid ${ }^{[4]}$ and organic heterocycles ${ }^{[5]}$ have been explored as potential hydrogen molecular storages. Although, their $\mathrm{H}_{2}$ storage ability could be considered relatively low from the point of view of percentage weight of hydrogen, organosilanes stand out because they are easily handy and storable, and the hydrolysis of Si-H bonds is thermodynamically favoured. Moreover, their hydrolysis produces not only hydrogen but also other products of commercial value such as silanols or polysiloxanes. ${ }^{[3]}$

Nevertheless, although the hydrolysis of $\mathrm{Si}-\mathrm{H}$ bonds is thermodynamically favourable, the reaction is kinetically slow. Therefore, catalysts are required to facilitate the activation of the $\mathrm{Si}-\mathrm{H}$ bond. However, only a few examples of homogeneous ${ }^{[6]}$ and heterogeneous ${ }^{[7]}$ effective catalytic systems have been reported so far.

One of our research interests during the last few years has been the study of the various applications of hydrosilanes in organometallic chemistry and catalysis. ${ }^{[8,9]}$ These investigations allowed the synthesis of $\left[\mathrm{Ir}(\mathrm{H})\left(\mathrm{CF}_{3} \mathrm{SO}_{3}\right)(\mathrm{NSiN})(\mathrm{coe})\right](\mathbf{1})(\mathrm{NSiN}=$ bis(pyridine-2-yloxy)methylsilyl fac-coordinated, coe = cyclooctene) which has proven to be an effective catalyst for $\mathrm{CO}_{2}$ hydrosilylation. ${ }^{[10]}$ Studies on the reactivity of $\mathbf{1}$ towards hydrosilanes evidenced a remarkable versatility and great potential for various catalytic applications involving hydrosilanes. Here we report on the catalytic activity of $\mathbf{1}$ as catalyst precursor for hydrogen and silanols production from the hydrolysis of hydrosilanes. Moreover a mechanistic insight of this iridiumcatalyzed process including DFT-calculations is reported.

\section{Results and Discussion}

Reactivity of 1 with $\mathrm{Et}_{3} \mathrm{SiH} .{ }^{1} \mathrm{H}$ and ${ }^{29} \mathrm{Si}\left\{{ }^{1} \mathrm{H}\right\}$ NMR studies of the reaction of complex 1 with one equivalent of $\mathrm{Et}_{3} \mathrm{SiH}$ in acetonitrile$\mathrm{d}_{3}$ at $85^{\circ} \mathrm{C}$ reveal the formation of the new hydride containing species 3a together with free coe, cyclooctane and traces of 4 and $\mathrm{Et}_{3} \mathrm{SiOSiEt}_{3}$ after 3.5 hours. As expected, heating of acetonitrile solutions of complex 1 at $85^{\circ} \mathrm{C}$ evidenced to the formation of free coe and species $3 \mathbf{a}$ The ${ }^{1} \mathrm{H}$ and ${ }^{13} \mathrm{C}\left\{{ }^{1} \mathrm{H}\right\}$ NMR spectra of $\mathbf{3 a}$ confirm the substitution of the coe ligand by one molecule of acetonitrile. Accordingly, the resonance corresponding to the $\mathrm{Ir}-\mathrm{H}$ proton appears at $\delta-19.49 \mathrm{ppm}$, up field shifted with respect to the value of $\delta-14.55 \mathrm{ppm}$ found for the $\mathrm{Ir}-\mathrm{H}$ resonance in $\mathbf{1}^{[10]}$ The remaining resonances of the ${ }^{1} \mathrm{H}$, ${ }^{13} \mathrm{C},{ }^{29} \mathrm{Si}\left\{{ }^{1} \mathrm{H}\right\}$ and ${ }^{19} \mathrm{~F}$ NMR spectra are consistent with the structure proposed for complex $\mathbf{3 a}$ in Scheme 1 (see experimental).

These observations are in agreement with the reaction pathway proposed in Scheme 1. A first step implies coe dissociation and generation of the unsaturated intermediate 2 which coordinates one molecule of NCMe to afford a solution containing the $\mathrm{Ir}-\mathrm{H}$ species $\mathbf{3 a}$ and free coe. This mixture evolves in presence of an excess of $\mathrm{Et}_{3} \mathrm{SiH}$ at $85{ }^{\circ} \mathrm{C}$ to give the $\mathrm{Ir}-\mathrm{SiEt}_{3}$ complex 4 and

[a] Dr. K. Garcés, Dr. F. J. Fernández-Alvarez, Dr. R. Lalrempuia, Prof. J. J. Pérez-Torrente and Prof. L. A. Oro Departamento de Química Inorgánica-ISQCH Universidad de Zaragoza - CSIC

Facultad de Ciencias 50009, Zaragoza - Spain. E-mail:paco@unizar.es, oro@unizar.es

[b] Dr. Víctor Polo

Departamento de Química Física - Instituto de Biocomputación y Física de Sistemas complejos (BIFI)

Universidad de Zaragoza

Facultad de Ciencias 50009, Zaragoza - Spain.

Supporting information for this article is available on the WWW under $h$ ttp://dx.doi.org/10.1002/cctc.200xxxxxx.((Please delete if not appropriate)) 
cyclooctane. Thus, treatment of acetonitrile solutions of 1 with an excess of $\mathrm{Et}_{3} \mathrm{SiH}$ (see experimental) at $85^{\circ} \mathrm{C}$ during $4 \mathrm{~h}$ leads to the formation of complex 4 , which was isolated as a yellow solid in $78 \%$ yield. Interestingly, despite the large excess of silane the selective reduction of coe to cyclooctane was always observed.

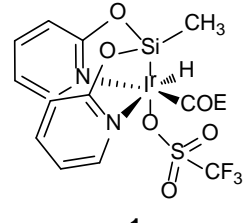
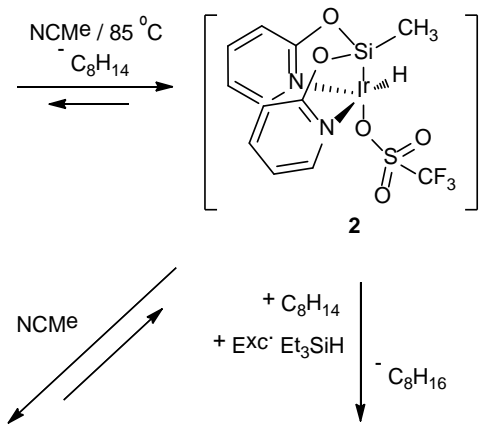

$+\mathrm{C}_{8} \mathrm{H}_{14}$
$+\mathrm{EXC}^{\cdot} \mathrm{Et}_{3} \mathrm{SiH}$

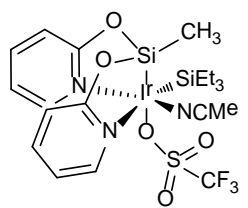

Scheme 1. Reaction pathway proposed for the reaction of 1 with excess of $\mathrm{Et}_{3} \mathrm{SiH}$ in acetonitrile at $85^{\circ} \mathrm{C}$.

Compound $\mathbf{4}$ was characterized in solution by means of ${ }^{1} \mathrm{H},{ }^{13} \mathrm{C}$, ${ }^{19} \mathrm{~F}$ and ${ }^{29} \mathrm{Si}\left\{{ }^{1} \mathrm{H}\right\}$ NMR spectroscopy. ${ }^{1} \mathrm{H}$ NMR spectra of acetonitrile- $d_{3}$ solutions of complex 4 confirm the presence of the $\mathrm{SiEt}_{3}$ moiety, which shows a multiplet between $\delta 0.60$ and 0.53 ppm and a triplet centered at $\delta 0.83 \mathrm{ppm}\left(\mathrm{J}_{\mathrm{H}-\mathrm{H}}=7.8 \mathrm{~Hz}\right)$ corresponding to the $\mathrm{CH}_{2}$ and $\mathrm{CH}_{3}$ protons of the ethyl groups, respectively. Each of these resonances show a direct $\mathrm{C}-\mathrm{H}$ bond correlation in the heteronuclear single quantum correlation (HSQC) spectra with one signal in the ${ }^{13} \mathrm{C}\left\{{ }^{1} \mathrm{H}\right\}$ NMR spectra, which can be assigned to the $\mathrm{CH}_{2}$ and $\mathrm{CH}_{3}$ carbon atoms of the $\mathrm{SiEt}_{3}$ group that appear at $\delta 7.1 \mathrm{ppm}$ and $\delta 8.9 \mathrm{ppm}$, respectively. The coordination of one acetonitrile molecule to the iridium center has been confirmed by the presence of the corresponding singlet resonances at $\delta 2.30$ and $4.4 \mathrm{ppm}$ in the ${ }^{1} \mathrm{H}$ and ${ }^{13} \mathrm{C}\left\{{ }^{1} \mathrm{H}\right\}$ spectra of 4 , respectively. The remaining ${ }^{1} \mathrm{H},{ }^{13} \mathrm{C},{ }^{29} \mathrm{Si}\left\{{ }^{1} \mathrm{H}\right\}$ and ${ }^{19} \mathrm{~F}$ resonances are consistent with the structure proposed for complex 4 in Scheme 1 (see experimental). ${ }^{29} \mathrm{Si}\left\{{ }^{1} \mathrm{H}\right\}$ NMR spectra of 4 show two resonances, one at $\delta-8.7 \mathrm{ppm}$ which show a Si-H correlation in the heteronuclear multiple bond correlation ${ }^{1} \mathrm{H}-{ }^{29} \mathrm{Si}$ $\mathrm{HMBC}$ spectra with the resonances assigned to the $\mathrm{SiEt}_{3}$ group in the ${ }^{1} \mathrm{H}$ NMR spectra, and another at $\delta 35.1 \mathrm{ppm}$ which correlates with the $\mathrm{SiCH}_{3}$ resonance of the NSiN ligand in the ${ }^{1} \mathrm{H}$ NMR spectra (Figure 1).

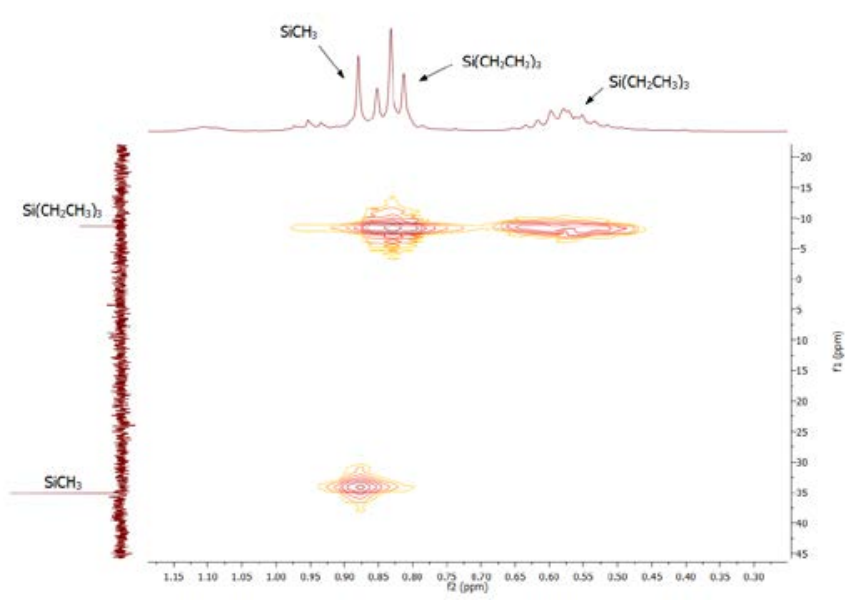

Figure 1. ${ }^{1} \mathrm{H}^{-29} \mathrm{Si} \mathrm{HMBC}$ spectrum of compound $\mathbf{4}$ in acetonitrile- $\mathrm{d}_{3}$.

The stereochemistry of compound $\mathbf{4}$ was unambiguously determined by means of nuclear overhauser enhancement (or effect) spectroscopy (NOESY). Interestingly, ${ }^{1} \mathrm{H}-{ }^{1} \mathrm{H}$ NOESY spectra of $\mathbf{4}$ show that the $\mathrm{SiEt}_{3}$ group has a dipole-dipole interaction through space with the low field shifted proton of one of the $\mathrm{N}$-heterocyclic rings of the $\mathrm{NSiN}$ ligand and has no interaction with the relative proton of the other ring (Figure 2). Additionally, a clear NOE effect was observed between the protons of the acetonitrile ligand and the $\mathrm{SiEt}_{3}$ group. These observations confirm the structure proposed for complex 4 (Scheme 1) in which the $\mathrm{SiEt}_{3}$ and MeCN ligands are coordinated trans to the $\mathrm{N}$-heterocyclic rings of the NSiN ligand.

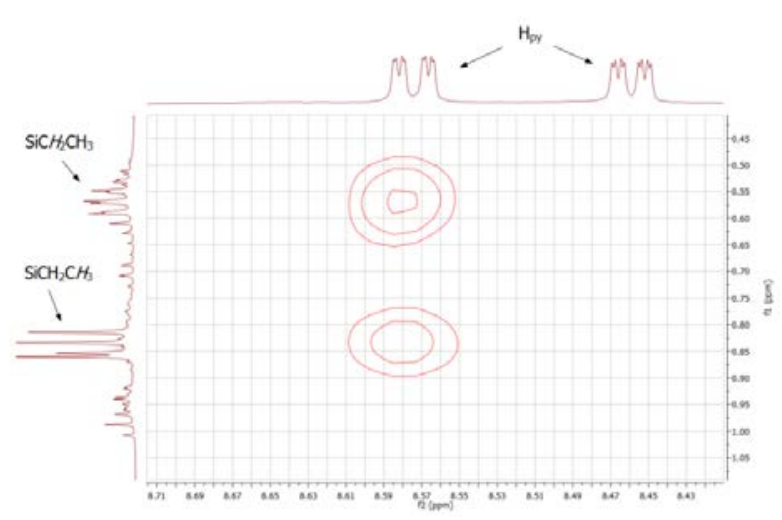

Figure $2 .{ }^{1} \mathrm{H}-{ }^{1} \mathrm{H}$ NOESY spectrum of compound 4 in acetonitrile- $\mathrm{d}_{3}$.

NMR studies on Iridium-catalyzed hydrogen production from $\mathrm{Et}_{3} \mathrm{SiH}$ and water. We were interested in the evaluation of the potential application of complex $\mathbf{1}$ as catalyst for $\mathrm{H}_{2}$ generation by hydrolysis of hydrosilanes. The results described above evidenced that the unsaturated species 2 , generated by reaction of $\mathbf{1}$ with hydrosilanes, can be stabilized in coordinating solvents such as acetonitrile to afford species $\mathbf{3 a}$. Therefore, we performed ${ }^{1} \mathrm{H},{ }^{13} \mathrm{C}\left\{{ }^{1} \mathrm{H}\right\}$ and ${ }^{29} \mathrm{Si}\left\{{ }^{1} \mathrm{H}\right\}$ NMR studies of the reaction of $\mathrm{Et}_{3} \mathrm{SiH}$ with $\mathrm{H}_{2} \mathrm{O}$ in $\mathrm{CD}_{2} \mathrm{Cl}_{2}$, a less coordinating solvent, in presence of catalytic amounts of 1 (1.0 mol \%). These experiments showed that the reaction products depend on the $\mathrm{H}_{2} \mathrm{O}$ concentration (Scheme 2). Thus, using 0.5 equiv of $\mathrm{H}_{2} \mathrm{O}$, hydrogen and $\mathrm{Et}_{3} \mathrm{SiOSiEt}_{3}{ }^{[11]}$ were the only reaction products after $1.5 \mathrm{~h}$ at $20^{\circ} \mathrm{C}$. 
However, the addition of an excess of $\mathrm{H}_{2} \mathrm{O}$ (5 equiv) under analogous reaction conditions resulted in the formation of $\mathrm{Et}_{3} \mathrm{SiOH}^{[12]}$ and $\mathrm{H}_{2}$ after $0.3 \mathrm{~h}$. In all the cases traces of cyclooctane coming from the catalyst activation process were observed.

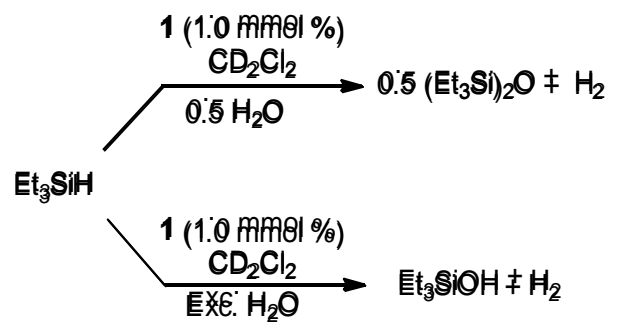

Scheme 2. $\mathrm{H}_{2}$ generation by hydrolysis of $\mathrm{Et}_{3} \mathrm{SiH}$ using $1(1.0 \mathrm{~mol} \%)$ as precatalyst in $\mathrm{CD}_{2} \mathrm{Cl}_{2}$.

Study of the hydrogen generation during the hydrolysis processes. The results of the NMR studies described above evidenced that complex $\mathbf{1}$ is an active precatalyst for hydrogen generation from the hydrolysis of $\mathrm{Et}_{3} \mathrm{SiH}$. These results stimulated us to deepen the study of such catalytic process. Thus, a variety of hydrosilanes were hydrolyzed in presence of catalytic amounts of $1(1.0 \mathrm{~mol} \%)$. The catalytic reactions were carried out in a micro-reactor and monitored by measuring the hydrogen pressure generated during the hydrolysis processes. The resulting liquid residues were studied by ${ }^{1} \mathrm{H},{ }^{13} \mathrm{C}\left\{{ }^{1} \mathrm{H}\right\}$ and ${ }^{29} \mathrm{Si}$ NMR spectroscopy in order to identified the silicon containing reactions products. These studies confirm that complex $\mathbf{1}$ is an effective precatalyst for $\mathrm{H}_{2}$ generation processes by hydrosilanes hydrolysis.

The turnover frequency (TOF) of these processes depends on the nature of the hydrosilane (see Table 1 and Figure 3). Interestingly, under the same reaction conditions the generation of $\mathrm{H}_{2}$ from the hydrolysis of the $\mathrm{Si}-\mathrm{H}$ bond of $\mathrm{MePh}_{2} \mathrm{SiH}$ and $\mathrm{Me}\left(\mathrm{Me}_{3} \mathrm{SiO}\right)_{2} \mathrm{SiH}$ is slower than from $\mathrm{Et}_{3} \mathrm{SiH}$ and $\mathrm{Me}_{2} \mathrm{PhSiH}$, which could be attributed to the greater steric hindrance around the silicon atom in $\mathrm{MePh}_{2} \mathrm{SiH}$ and $\mathrm{Me}\left(\mathrm{Me}_{3} \mathrm{SiO}\right)_{2} \mathrm{SiH}$ (Table 1). ${ }^{[6 \mathrm{a}]}$ In all the cases, a noticeable enhancement of the TOF values was observed when THF was used as solvent. Remarkably, high TOF $_{1 / 2}$ values were found from the hydrolysis of $\mathrm{Me}_{2} \mathrm{PhSiH}\left(50400 \mathrm{~h}^{-1}\right)$ and $\mathrm{Et}_{3} \mathrm{SiH}$ $\left(1890 \mathrm{~h}^{-1}\right)$ in THF using $1(1 \mathrm{~mol} \%)$ as catalsyt precursor (entries 2 and 7 in Table 1). It is worth mentioning that when the hydrolysis reactions were conducted in $\mathrm{CH}_{2} \mathrm{Cl}_{2}$ the selective formation of the corresponding silanol was always observed. However, mixtures containing silanol as major component together with the corresponding siloxane were obtained from the hydrolysis of $\mathrm{Me}_{2} \mathrm{PhSiH}$ and $\mathrm{Me}\left(\mathrm{Me}_{3} \mathrm{SiO}\right)_{2} \mathrm{SiH}$ in THF (entries 7 and 9 Table 1). Interestingly, we did not observe reaction of $\mathrm{Et}_{3} \mathrm{SiH}$ with excess of $\mathrm{H}_{2} \mathrm{O}$ in absence of complex 1 (entry 3 Table $1)$.

\begin{tabular}{|c|c|c|c|c|}
\hline Entry & $\begin{array}{c}\text { Silane } \\
(1.0 \mathrm{mmol})\end{array}$ & $\begin{array}{c}{\left[\mathrm{H}_{2}\right]} \\
(\mathrm{mmol})\end{array}$ & $\mathrm{R}_{3} \mathrm{SiOH} /\left(\mathrm{R}_{3} \mathrm{Si}_{2} \mathrm{O}^{[\mathrm{b}]}\right.$ & $\begin{array}{c}\operatorname{TOF}_{1 / 2}^{[c]} \\
\left(\mathrm{h}^{-1}\right)\end{array}$ \\
\hline 1 & $\mathrm{Et}_{3} \mathrm{SiH}^{[\mathrm{d}]}$ & 0.95 & $>99 / 0$ & 510 \\
\hline 2 & $\mathrm{Et}_{3} \mathrm{SiH}^{[\mathrm{e}]}$ & 0.96 & $>99 / 0$ & 1890 \\
\hline 3 & $\mathrm{Et}_{3} \mathrm{SiH}^{[\mathrm{ff}]}$ & - & - & - \\
\hline 4 & $\mathrm{MePh}_{2} \mathrm{SiH}^{[\mathrm{d}]}$ & 1.0 & $>99 / 0$ & 23 \\
\hline 5 & $\mathrm{MePh}_{2} \mathrm{SiH}^{[\mathrm{e}]}$ & 1.0 & $>99 / 0$ & 820 \\
\hline 6 & $\mathrm{Me}_{2} \mathrm{PhSiH}{ }^{[d]}$ & 1.0 & $>92 / 8$ & 3450 \\
\hline 7 & $\mathrm{Me}_{2} \mathrm{PhSiH}^{[\mathrm{e}]}$ & 0.97 & $65 / 35$ & 50400 \\
\hline 8 & $\mathrm{Me}\left(\mathrm{Me}_{3} \mathrm{SiO}\right)_{2} \mathrm{SiH}^{[\mathrm{dd}]}$ & 1.0 & $>99 / 0$ & 20 \\
\hline 9 & $\mathrm{Me}\left(\mathrm{Me}_{3} \mathrm{SiO}\right)_{2} \mathrm{SiH}^{[\mathrm{ee}]}$ & 1.0 & 70/n.d. ${ }^{[g]}$ & 130 \\
\hline
\end{tabular}

[a] $1.0 \mathrm{~mol} \%$ of 1 as precatalyst and 5.0 equivalents of water at r.t. [b] \% ratio based on NMR yield. [c] turnover frequency at $50 \%$ of conversion. [d] $\mathrm{CH}_{2} \mathrm{Cl}_{2}[\mathrm{e}]$ THF [f] $\mathrm{CH}_{2} \mathrm{Cl}_{2}$ without catalyst. [g] not determined.

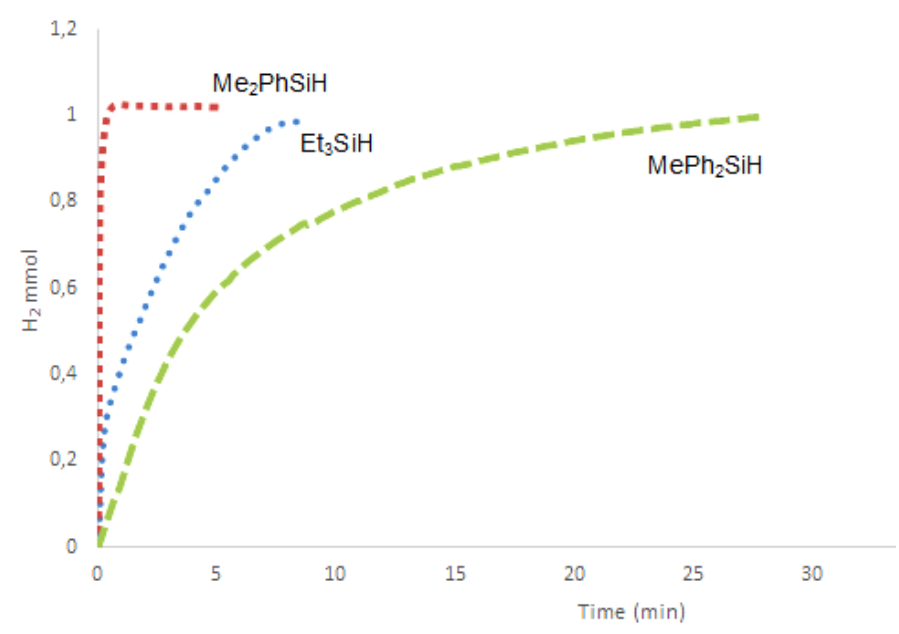

Figure 3. Hydrogen generation (mmol) versus time ( $\mathrm{min}$ ) for the catalytic hydrolysis of $\mathrm{Me}_{2} \mathrm{PhSiH}, \mathrm{Et}_{3} \mathrm{SiH}$ and $\mathrm{MePh}_{2} \mathrm{SiH}$ using $1(1.0 \mathrm{~mol} \%)$ as catalyst and 5.0 equivalents of water in THF.

We have also studied the catalytic hydrolysis of hydrosilanes which could potentially generate two equivalents of hydrogen per mol of silane such as $\mathrm{Et}_{2} \mathrm{SiH}_{2}$ and $\left(\mathrm{Me}_{2} \mathrm{HSi}\right)_{2} \mathrm{O}$ (Table 2, Figure 4). Slightly better reaction yields and higher TOF values were invariably obtained in the hydrolysis of $\mathrm{Et}_{2} \mathrm{SiH}_{2}$. The lower steric hindrance around the $\mathrm{Si}-\mathrm{H}$ bond in $\mathrm{Et}_{2} \mathrm{SiH}_{2}$ in comparison with $\left(\mathrm{Me}_{2} \mathrm{HSi}\right)_{2} \mathrm{O}$ could explain the better perfomance observed when $\mathrm{Et}_{2} \mathrm{SiH}_{2}$ was used as hydrogen source. In both cases, higher TOF $_{1 / 2}$ values were also obtained in THF (entries 2 and 4 Table 2). It is worth mentioning that these values, 107140 and $96770 \mathrm{~h}^{-1}$, are the highest reported so far. ${ }^{[6]}$ 


\begin{tabular}{|c|c|c|c|c|}
\hline Entry & $\begin{array}{c}\text { Silane } \\
(0.5 \mathrm{mmol})\end{array}$ & $\begin{array}{c}{\left[\mathrm{H}_{2}\right]} \\
(\mathrm{mmol})\end{array}$ & $\begin{array}{c}\text { Yield } \\
\left(\% \text { of } \mathrm{H}_{2}\right)\end{array}$ & $\begin{array}{c}\operatorname{TOF}_{1 / 2}[\mathrm{~b}] \\
\left(\mathrm{h}^{-1}\right)\end{array}$ \\
\hline 1 & $\mathrm{Et}_{2} \mathrm{SiH}_{2}^{[c]}$ & 0.88 & 88 & 6680 \\
\hline 2 & $\mathrm{Et}_{2} \mathrm{SiH}_{2}{ }^{[\mathrm{d}]}$ & 0.86 & 86 & 107140 \\
\hline 3 & $\left(\mathrm{Me}_{2} \mathrm{HSi}\right)_{2} \mathrm{O}^{[c]}$ & 0.78 & 78 & 2750 \\
\hline 4 & $\left(\mathrm{Me}_{2} \mathrm{HSi}\right)_{2} \mathrm{O}^{[\mathrm{d}]}$ & 0.76 & 76 & 96770 \\
\hline
\end{tabular}

[a] $1.0 \mathrm{~mol} \%$ of 1 as precatalyst and 5.0 equivalents of water at r.t. [b] turnover frequency at $50 \%$ of conversion [c] $\mathrm{CH}_{2} \mathrm{Cl}_{2}$ [d] THF.

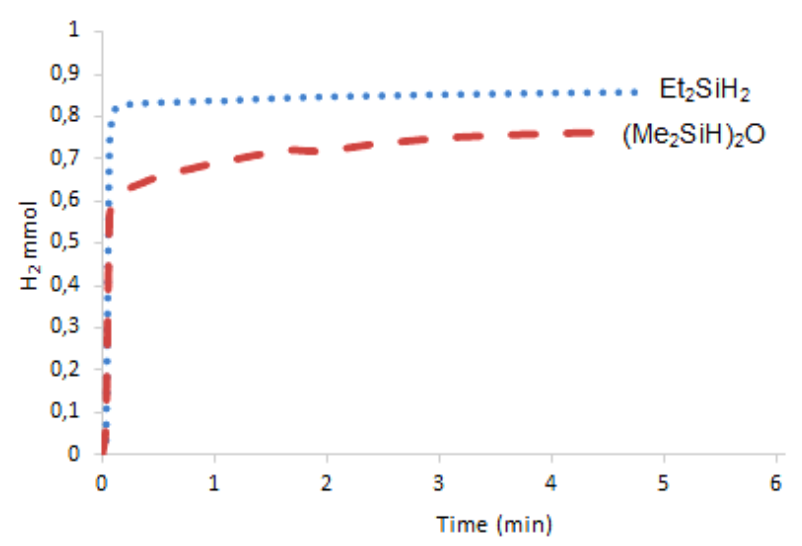

Figure 4. Hydrogen generation (mmol) versus time (min) for the catalytic hydrolysis of $\mathrm{Et}_{2} \mathrm{SiH}_{2}$ and $\left(\mathrm{Me}_{2} \mathrm{SiH}\right)_{2} \mathrm{O}$ using $1(1.0 \mathrm{~mol} \%)$ as catalyst and 5.0 equivalents of water in THF.

The results shown in Tables 1 and 2 demonstrate that complex 1 efficiently catalyzes hydrogen generation by organosilanes hydrolysis, being one of the most active catalytic systems reported so far. ${ }^{[6]}$

We have also studied the solvent-free catalytic hydrolysis of $\mathrm{Me}\left(\mathrm{Me}_{3} \mathrm{SiO}\right)_{2} \mathrm{SiH}$ and $\left(\mathrm{Me}_{2} \mathrm{HSi}\right)_{2} \mathrm{O}$ using complex $1(1.0 \mathrm{~mol} \%)$ as catalyst (Table 3). Interestingly, the solvent free catalytic system is also effective for hydrogen generation. The reaction of $\mathrm{Me}\left(\mathrm{Me}_{3} \mathrm{SiO}\right)_{2} \mathrm{SiH}$ with 5.0 equivalents of water produces the quantitative amount of hydrogen with a $\mathrm{TOF}_{1 / 2}=22$. This activity compares well to that obtained in $\mathrm{CH}_{2} \mathrm{Cl}_{2}$ (entry 8, Table 1). However, an activity decrease was observed for $\left(\mathrm{Me}_{2} \mathrm{HSi}\right)_{2} \mathrm{O}$ (entry 2 Table 3) both in $\mathrm{CH}_{2} \mathrm{Cl}_{2}$ or THF, which can be explained by the poor solubility of the catalytst in $\left(\mathrm{Me}_{2} \mathrm{HSi}\right)_{2} \mathrm{O}$.

\begin{tabular}{l}
\hline \multicolumn{4}{|c|}{$\begin{array}{l}\text { Table 3. Solvent free Hydrogen generation by } \\
\text { of siloxanes. }{ }^{[a]}\end{array}$} \\
\begin{tabular}{c|cccc|} 
Entry & $\begin{array}{c}\text { Silane } \\
(1.5 \mathrm{mmol})\end{array}$ & $\begin{array}{c}{\left[\mathrm{H}_{2}\right]} \\
(\mathrm{mmol})\end{array}$ & $\begin{array}{c}\text { Yield } \\
\left(\% \text { of } \mathrm{H}_{2}\right)\end{array}$ & $\begin{array}{c}\text { TOF } \\
\left(\mathrm{h}^{-1}\right)\end{array}$ \\
\hline 1 & $\mathrm{Me}\left(\mathrm{Me}_{3} \mathrm{SiO}\right)_{2} \mathrm{SiH}$ & 1.50 & $>99$ & $22^{[\mathrm{b}]}$ \\
2 & $\left(\mathrm{Me}_{2} \mathrm{HSi}\right)_{2} \mathrm{O}$ & 1.02 & 34 & $27^{[\mathrm{c}]}$ \\
\hline
\end{tabular}
\end{tabular}

[a] $1.0 \mathrm{~mol} \%$ of $\mathbf{1}$ as precatalyst and 5.0 equivalents of water at r.t. [b] turnover frequency at $50 \%$ of conversion. [c] turnover frequency at the end of the reaction.
Mechanistic studies. Heating of acetonitrile solutions of complex $\mathbf{1}$ at $85^{\circ} \mathrm{C}$ leads to the formation of free coe and species $\mathbf{3 a}$. Thus, under an excess of silanes it would be reasonable to assume the possible coordination of one molecule of silane to the unsaturated species 2 (Scheme 1) to give the $\operatorname{Ir}-\left(\eta^{3}-\mathrm{HSiR}_{3} \mathrm{H}\right)$ species $\mathbf{5}$ (Scheme 3). ${ }^{[13]}$ Indeed, DFT calculations show that the coordination of one molecule of silane is 14.8 and $17.6 \mathrm{kcalmol}^{-1}$ more favourable than the coordination of one molecule of $\mathrm{CH}_{2} \mathrm{Cl}_{2}$ or THF, respectively. Additionally, the coordination of one molecule of water to $\mathbf{2}$ is isoenergetic with the formation of species $\mathbf{5}$.

Theoretical calculations at DFT level using $\mathrm{Me}_{3} \mathrm{SiH}$ as model system evidenced that the reaction mechanism of this iridiumcatalyzed silane hydrolysis process can be viewed as a stepwise process. Initially, the $\mathrm{Si}-\mathrm{H}$ bond coordinated to the iridium centre is activated by a water molecule, according to a $\mathrm{S}_{\mathrm{N}} 2$ type mechanism, leading to an ionic pair intermediate (Figure 5). In a second step, water splitting is achieved by proton transfer from the cationic moiety of the ionic pair to one of the hydrides forming molecular hydrogen (Figure 6).

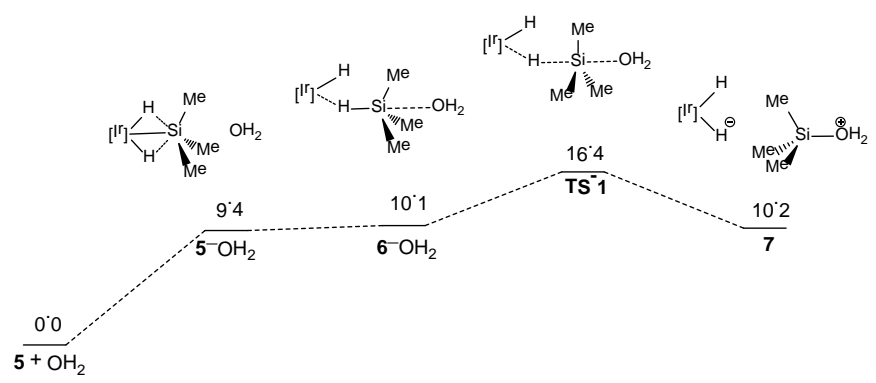

Figure 5. DFT calculated free energy profile for the $\mathrm{Si}-\mathrm{H}$ bond activation process $\left(\Delta \mathrm{G} \mathrm{kcal} \mathrm{mol}{ }^{-1}\right.$, relative to 5 and free water).

Interestingly, under these conditions species $\mathbf{5}$ is in equilibrium with complex $\mathbf{6}^{[14]}$ (Figure 5). The interaction of $\mathbf{6}$ with a molecule of water leads to TS-1 with a relative free energy of $16.4 \mathrm{kcalmol}^{-1}$ This transition structure is very flat (lowest frequency of $-87.9 \mathrm{~cm}$ ${ }^{1}$ ) and it is associated to the $\mathrm{Si}-\mathrm{H}$ bond breaking and $\mathrm{Si}-\mathrm{O}$ bond formation. The resulting complex $\mathbf{7}$ is described as an ionic pair, being the interaction between both moieties of electrostatic nature (Figure 5). ${ }^{[14 b, 15]}$

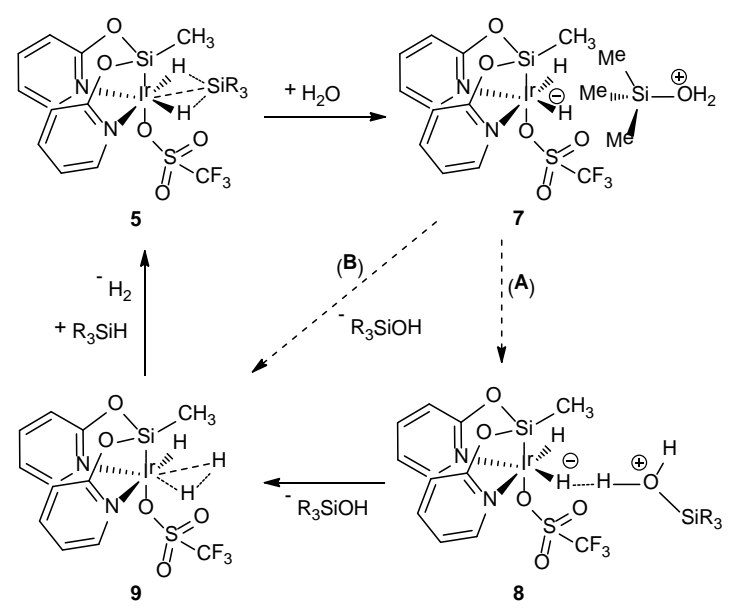

Scheme 3. Mechanistic proposal for the iridium-catalyzed hydrolysis of silanes. 
A proton transfer between the cationic and anionic moieties in 7 results in the formation of silanol and the hydrido/dihydrogen intermediate 9. This process can take place through two different ways (see Scheme 3): i) without assistance of additional water molecules, path $(\mathbf{A})$, or ii) water-assisted according to the Grotthuss mechanism, path (B). Hence, following path (A), a dihydrogen interaction, ${ }^{[18]}$ between the metal hydride moiety and one of the $\mathrm{O}-\mathrm{H}$ bonds of the activated water molecule $(\mathrm{Ir}-\mathrm{H} \cdot \cdot \cdot \mathrm{H}$ $\mathrm{OH}, \mathrm{d}_{\mathrm{H}-\mathrm{H}}=1.53 \AA$ ) stabilizes complex 8 in $12.5 \mathrm{kcalmol}^{-1}$. Then, a transition structure TS-2 is found presenting a very low free energy barrier $\left(2.9 \mathrm{kcalmol}^{-1}\right)$. The geometry of TS-2 is shown in Figure 7 , pointing out the key geometrical parameters of the proton transfer process and the hydrogen bond formed between the triflate and the $\mathrm{O}-\mathrm{H}$ bond. The outcome of this reaction is exothermic $\left(-7.1 \mathrm{kcalmol}^{-1}\right)$ and silanol and complex 9 are formed. The same species can be obtained through a water assisted proton transfer mechanism, ${ }^{[19]}$ path (B) although no transition structure could be located due the barrierless nature of the process.

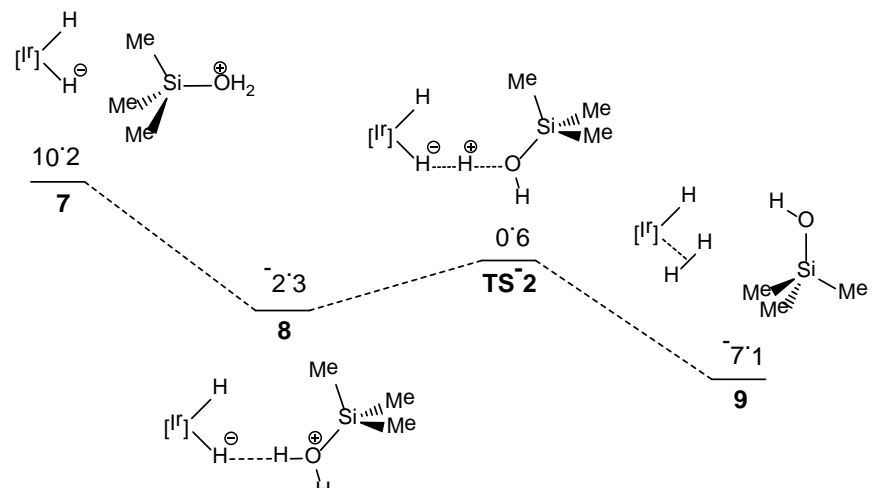

Figure 6. DFT calculated free energy profile for the formation of intermediate 9 from 7 ( $\Delta \mathrm{G} \mathrm{kcal} \mathrm{mol}{ }^{-1}$, relative to $\mathbf{5}$ and free water) through path $(\mathbf{A})$

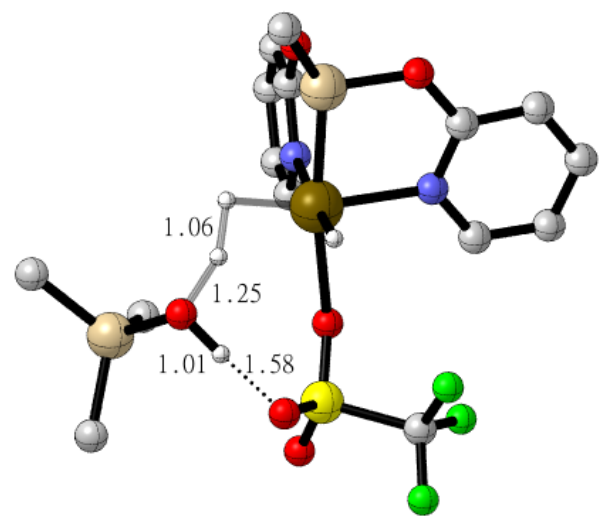

Figure 7. DFT optimized geometry of TS-2. Key distances are in $\AA$. Hydrogen atoms bonded to carbon atoms are not displayed for clarity.

The calculated $\mathrm{H}-\mathrm{H}(0.94 \AA)$ and $\mathrm{Ir}-\mathrm{H}_{2}(1.59 \AA)$ bond distances found for the $\operatorname{Ir}\left(\eta^{2}-\mathrm{H}_{2}\right)$ moiety in $\mathbf{9}$ confirm the lability of the dihydrogen ligand. ${ }^{[16]}$ In agreement with the frequent reactivity of $\operatorname{Ir}(I I I)$ species containing labile dihydrogen ligands, ${ }^{[17]}$ we propose that the dihydrogen ligand of $\mathbf{9}$ can be displaced by an additional molecule of silane to regenerate the active species $\mathbf{5}$ (Scheme 3). As expected, when the reaction is performed with $\mathrm{D}_{2} \mathrm{O}(99.90 \%)$ in THF- $\mathrm{d}_{8}$ the selective formation of H-D has been unambiguously observed by ${ }^{1} \mathrm{H}$ NMR spectroscopy (see supporting information). It is worth to note that the highest energetic barrier of the overall process, $16.4 \mathrm{kcal} \mathrm{mol}^{-1}$, corresponds to the water assisted $\mathrm{Si}-\mathrm{H}$ bond activation process (Figure 5) which agrees with the experimental finding of the relationship between the steric hindrance of the silicon atom and the efficiency of the process (Table 1).

\section{Conclusion}

The iridium(III) complex $\left[\mathrm{Ir}(\mathrm{H})\left(\mathrm{CF}_{3} \mathrm{SO}_{3}\right)(\mathrm{NSiN})(\mathrm{coe})\right]$ (1) has proven to be an excellent catalyst precursor for hydrogen generation by silanes hydrolysis. The turnover frequency (TOF) depends both on the solvent and the nature of the hydrosilane. It is worth mentioning that under the same reaction conditions the generation of $\mathrm{H}_{2}$ from catalytic hydrolysis of the $\mathrm{Si}-\mathrm{H}$ bond of hydrosilanes is related with the steric hindrance around the silicon atom. In accordance with this finding, less bulky silanes are more active.

In all the cases, a noticeable enhancement of the TOF values was observed when THF was used as solvent compared to $\mathrm{CH}_{2} \mathrm{Cl}_{2}$. Remarkably, high $\mathrm{TOF}_{1 / 2}$ values were found from the hydrolysis of $\mathrm{Et}_{2} \mathrm{SiH}_{2}\left(107140 \mathrm{~h}^{-1}\right),\left(\mathrm{Me}_{2} \mathrm{HSi}\right)_{2} \mathrm{O}\left(96770 \mathrm{~h}^{-1}\right)$ and $\mathrm{MePh}_{2} \mathrm{SiH}\left(50400 \mathrm{~h}^{-1}\right)$ in THF. Interestingly, solvent free reactions using $\mathrm{Me}\left(\mathrm{Me}_{3} \mathrm{SiO}\right)_{2} \mathrm{SiH}$ or $\left(\mathrm{Me}_{2} \mathrm{HSi}\right)_{2} \mathrm{O}$ as hydrogen source also produce molecular hydrogen.

Finally, a reaction mechanism for this iridium-catalyzed silane hydrolysis process has been proposed based on both experimental data and theoretical calculations. The overall catalytic cycle can be view as a two stages process involving: i) the water promoted $\mathrm{Si}-\mathrm{H}$ bond activation which is followed by ii) the water splitting process via a proton transfer.

Summarizing, compound $\mathbf{1}$ is an efficient catalyst precursor for the generation of molecular hydrogen under mild conditions (298 $\mathrm{K})$ from the hydrolysis of not sterically hindered hydrosilanes in THF.

\section{Experimental Section}

General information. All manipulations were performed with rigorous exclusion of air at an argon/vacuum manifold using standard Schlenktube techniques or in a dry-box (MB-UNILAB). Solvents were dried by the usual procedures and distilled under argon prior to use or taken under argon from a Solvent Purification System (SPS). $\mathrm{Et}_{3} \mathrm{SiH}$, $\mathrm{MePh}_{2} \mathrm{SiH}, \mathrm{Me}_{2} \mathrm{PhSiH}, 1,1,1,3,5,5,5$-heptamethyltrisiloxane, $\mathrm{Et}_{2} \mathrm{SiH}_{2}$ and $\left(\mathrm{Me}_{2} \mathrm{SiH}\right)_{2} \mathrm{O}$ were purchased from commercial sources and dried with molecular sieves $4 \mathrm{~A}$ previously to use. The starting material $\left[\operatorname{lr}(\mathrm{H})\left(\mathrm{CF}_{3} \mathrm{SO}_{3}\right)(\mathrm{NSiN})(\mathrm{coe})\right]$ (1) was prepared according with the literature procedure. ${ }^{[10]}$ NMR spectra were recorded on a Varian Gemini 2000, Bruker ARX 300, Bruker Avance $300 \mathrm{MHz}$ or Bruker Avance $400 \mathrm{MHz}$ instrument. Chemical shifts (expressed in parts per million) are referenced to residual solvent peaks $\left({ }^{1} \mathrm{H},{ }^{13} \mathrm{C}\left\{{ }^{1} \mathrm{H}\right\}\right)$. Coupling constants, J, are given in hertz. $\mathrm{C}, \mathrm{H}$, and $\mathrm{N}$ analyses were carried out in a Perkin-Elmer $2400 \mathrm{CHNS} / \mathrm{O}$ analyser. High-resolution electrospray mass spectra were acquired using a MicroTOF-Q hybrid quadrupole time-of-flight spectrometer (Bruker Daltonics, Bremen, Germany). The intensity of the mass relative to that of the base peak is given in parentheses after the found mass. $\mathrm{H}_{2}$ evolution was measured using a Man on the Moon series X102 kit (www.manonthemoontech.com), which monitors the variation of pressure and temperature of the gas phase inside a closed reaction flask. The reaction vessel is connected to a switchable 3-way valve via a Thorion screw through polyamide tubing. The valve can be switched between two positions, one of them connecting the reactor vessel to the exterior so that it can be used like a conventional Schlenk flask. The other position connects the flask to the pressure transducer, thus closing the system. 
Reaction of 1 with one equivalent of $\mathrm{Et}_{3} \mathrm{SiH}$ in acetonitrile- $\mathrm{d}_{3}$. An NMR tube containing a solution of $1(0.032 \mathrm{~g}, 0.05 \mathrm{mmol})$ in $0.5 \mathrm{~mL}$ of acetonitrile- $d_{3}$ was treated with 1.0 equiv of triethylsilane $(7.4 \mu \mathrm{L}, 0.05$ mmol). The sample was heated at $85{ }^{\circ} \mathrm{C}$ and monitored by NMR periodically. ${ }^{1} \mathrm{H}$ NMR spectra after $3.5 \mathrm{~h}$ showed a quantitative conversion to the new species $\left[\mathrm{IrH}\left(\mathrm{CF}_{3} \mathrm{SO}_{3}\right)\left(\mathrm{CH}_{3} \mathrm{CN}\right)(\mathrm{NSiN})\right]$ (3a) together with traces of 4 and of $\mathrm{Et}_{3} \mathrm{SiOSiEt}_{3}$. Data for $3 \mathrm{a} .{ }^{1} \mathrm{H}$ NMR $\left(400.13 \mathrm{MHz}, \mathrm{CD}_{3} \mathrm{CN}, 298 \mathrm{~K}\right.$ ): $\delta 8.60$ (ddd, $\mathrm{J}_{\mathrm{H}-\mathrm{H}}=3.4,2.5,1.5,1 \mathrm{H}$ $\left.\mathrm{H}_{\mathrm{py}}\right), 8.55$ (ddd, $\left.J_{\mathrm{H}-\mathrm{H}}=6.2,1.7,0.5,1 \mathrm{H}, \mathrm{H}_{\mathrm{py}}\right), 7.82\left(\mathrm{ddd}, \mathrm{J}_{\mathrm{H}-\mathrm{H}}=8.4,7.3\right.$ $\left.1.9,1 \mathrm{H}, \mathrm{H}_{\mathrm{py}}\right), 7.68$ (ddd, $\left.J_{\mathrm{H}-\mathrm{H}}=8.5,7.3,1.8,1 \mathrm{H}, \mathrm{H}_{\mathrm{py}}\right), 7.09-7.04(\mathrm{~m}$, $\left.2 \mathrm{H}, \mathrm{H}_{\mathrm{py}}\right), 6.92$ (ddd, $\left.J_{\mathrm{H}-\mathrm{H}}=8.4,1.4,0.7,1 \mathrm{H}, \mathrm{H}_{\mathrm{py}}\right), 6.82$ (ddd, $J_{\mathrm{H}-\mathrm{H}}=7.4$ $\left.6.2,1.4,1 \mathrm{H}, \mathrm{H}_{\mathrm{py}}\right), 2.34\left(\mathrm{~s}, \mathrm{CH}_{3} \mathrm{CN}, 3 \mathrm{H}\right), 0.88\left(\mathrm{~s}, \mathrm{SiCH}_{3}, 3 \mathrm{H}\right),-19.49(\mathrm{~s}$, $\mathrm{IrH}, 1 \mathrm{H}) \cdot{ }^{13} \mathrm{C}\left\{{ }^{1} \mathrm{H}\right\}$-APT plus HMBC and HSQC NMR $(100.6 \mathrm{MHz}$, $\mathrm{CD}_{3} \mathrm{CN}, 298 \mathrm{~K}$ ): $\delta 168.4$ and 166.0 (both s, $\mathrm{C}_{\text {ipso-py), }}$ 151.3, 149.0 143.2 and 142.4 (all s, $\mathrm{C}_{\mathrm{py}}$ ), $120.7\left(\mathrm{~s}, \mathrm{CH}_{3} \mathrm{CN}\right.$ ), 119.4, 118.8, 113.6 and 112.8 (all s, $\mathrm{C}_{\mathrm{py}}$ ), $4.3\left(\mathrm{~s}, \mathrm{CH}_{3} \mathrm{CN}\right.$ ), $\left.-1.5\left(\mathrm{~s}, \mathrm{SiCH}_{3}\right) .{ }^{29} \mathrm{Si}{ }^{1} \mathrm{H}\right\} \mathrm{NMR}$ $\left(79.5 \mathrm{MHz}, \mathrm{CD}_{3} \mathrm{CN}, 298 \mathrm{~K}\right): \delta 35.1\left(\mathrm{~s}, \mathrm{SiCH}_{3}\right) .{ }^{19} \mathrm{~F} \mathrm{NMR}(282.4 \mathrm{MHz}$, $\left.\mathrm{CD}_{3} \mathrm{CN}, 298 \mathrm{~K}\right): \delta-79.3\left(\mathrm{~s}, \mathrm{CF}_{3}\right)$.

Preparation of $\left[\mathrm{Ir}\left\{\mathrm{Si}\left(\mathrm{CH}_{2} \mathrm{CH}_{3}\right)_{3}\right\}\left(\mathrm{CF}_{3} \mathrm{SO}_{3}\right)\left(\mathrm{CH}_{3} \mathrm{CN}\right)(\mathrm{NSiN})\right]$ (4). A solution of $1(0.228 \mathrm{~g}, 0.33 \mathrm{mmol})$ in $10 \mathrm{~mL}$ of acetonitrile was treated with 10 equiv of triethylsilane $(532 \mu \mathrm{L}, 3.33 \mathrm{mmol})$, and the mixture was heated to $85^{\circ} \mathrm{C}$ for $4 \mathrm{~h}$. The resulting solution was filtered through Celite, and the solvent was removed in vacuo. The addition of hexane $(3 \mathrm{~mL})$ led to a yellow solid, which was separated by decantation, washed with further portions of hexane $(10 \times 3 \mathrm{~mL})$ and pentane $(3 \times 3 \mathrm{~mL})$ and dried in vacuo. Yield: $191 \mathrm{mg}(78 \%)$. Anal. calcd. for $\mathrm{C}_{20} \mathrm{H}_{29} \mathrm{~F}_{3} \mathrm{IrN} \mathrm{N}_{3} \mathrm{O}_{5} \mathrm{SSi}_{2}$ (728.910): C, 32.96; H, 4.01; N, 5.76; S, 4.40. Found: $\mathrm{C}, 32.95 ; \mathrm{H}, 4.45 ; \mathrm{N}, 5.92, \mathrm{~S}, 4.10$. Mass spectrometry (HR-electrospray): $\mathrm{m} / \mathrm{z}[\mathrm{M}]$ calcd for $\mathrm{C}_{20} \mathrm{H}_{29} \mathrm{~F}_{3} \mathrm{IrN}_{3} \mathrm{O}_{5} \mathrm{SSi}_{2}$ 729.094, found 729.199 (34); [M]- $\left[\mathrm{CF}_{3} \mathrm{O}_{3} \mathrm{~S}\right]$ calcd for $\mathrm{C}_{19} \mathrm{H}_{29} \mathrm{IrN}_{3} \mathrm{O}_{2} \mathrm{Si}_{2} 580.142$ found 580.140 (100). ${ }^{1} \mathrm{H}$ NMR (400.13 MHz, $\left.\mathrm{CD}_{3} \mathrm{CN}, 298 \mathrm{~K}\right): \delta 8.57$ (ddd, $\left.J_{H-H}=6.2,1.8,0.6,1 \mathrm{H}, \mathrm{H}_{\mathrm{py}}\right), 8.46$ (ddd, $J_{\mathrm{H}-\mathrm{H}}=5.6,1.9,0.7,1 \mathrm{H}$ $\left.\mathrm{H}_{\mathrm{py}}\right), 7.82$ (ddd, $\left.\mathrm{J}_{\mathrm{H}-\mathrm{H}}=8.3,7.2,1.9,1 \mathrm{H}, \mathrm{H}_{\mathrm{py}}\right), 7.72$ (ddd, $\mathrm{J}_{\mathrm{H}-\mathrm{H}}=8.5,7.2$, $\left.1.8,1 \mathrm{H}, \mathrm{H}_{\mathrm{py}}\right), 7.09-7.02\left(\mathrm{~m}, 2 \mathrm{H}, \mathrm{H}_{\mathrm{py}}\right), 6.92\left(\mathrm{ddd}, \mathrm{J}_{\mathrm{H}-\mathrm{H}}=8.4,1.4,0.6\right.$ $\left.1 \mathrm{H}, \mathrm{H}_{\mathrm{py}}\right), 6.83$ (ddd, $\left.\mathrm{J}_{\mathrm{H}-\mathrm{H}}=7.4,6.2,1.4,1 \mathrm{H}, \mathrm{H}_{\mathrm{py}}\right), 2.30\left(\mathrm{~s}, \mathrm{CH}_{3} \mathrm{CN}, 3 \mathrm{H}\right)$, $0.86\left(\mathrm{~s}, \mathrm{SiCH}_{3}, 3 \mathrm{H}\right), 0.83\left(\mathrm{pt}, \mathrm{J}_{\mathrm{H}-\mathrm{H}}=7.8, \mathrm{CH}_{2} \mathrm{CH}_{3}, 9 \mathrm{H}\right), 0.60-0.53(\mathrm{~m}$ $\mathrm{CH}_{2} \mathrm{CH}_{3}, 6 \mathrm{H}$ ). The NOESY spectrum shows a cross-peak between the signals at 8.57 and 0.83 and $0.57 \mathrm{ppm}$ and other cross-peak between the signals at 2.30 and 0.83 and $0.57 \mathrm{ppm}$, among others. ${ }^{13} \mathrm{C}\left\{{ }^{1} \mathrm{H}\right\}$-APT plus HMBC and HSQC NMR $\left(75.5 \mathrm{MHz}, \mathrm{CD}_{3} \mathrm{CN}, 298 \mathrm{~K}\right)$ : $\delta 168.3$ and 164.7 (both s, $C_{\text {ipso }}$-py), 151.1, 147.8, 143.2 and 142.5 (all $\left.\mathrm{s}, \mathrm{C}_{\mathrm{py}}\right), 121.2$ (c, J $\left.\mathrm{J}_{\mathrm{C}-\mathrm{F}}=320.9, \mathrm{CF}_{3}\right), 120.9\left(\mathrm{~s}, \mathrm{CH}_{3} \mathrm{CN}\right), 119.5,118.9$ 113.8 and 113.1 (all s, $\left.\mathrm{C}_{\mathrm{py}}\right), 8.9\left(\mathrm{~s}, \mathrm{CH}_{2} \mathrm{CH}_{3}\right), 7.1\left(\mathrm{~s}, \mathrm{CH}_{2} \mathrm{CH}_{3}\right), 4.4(\mathrm{~s}$ $\left.\mathrm{CH}_{3} \mathrm{CN}\right),-0.6\left(\mathrm{~s}, \mathrm{SiCH}_{3}\right) .{ }^{29} \mathrm{Si}\left\{{ }^{1} \mathrm{H}\right\}$ plus ${ }^{29} \mathrm{Si}^{1}{ }^{1} \mathrm{H} \mathrm{HMBC} \mathrm{NMR}(59.6 \mathrm{MHz}$ $\left.\mathrm{CD}_{3} \mathrm{CN}, 298 \mathrm{~K}\right): \delta 35.1\left(\mathrm{~s}, \mathrm{SiCH}_{3}\right),-8.7\left(\mathrm{~s}, \mathrm{Si}\left(\mathrm{CH}_{2} \mathrm{CH}_{3}\right)_{3}\right) .{ }^{19} \mathrm{~F} \mathrm{NMR}$ (376.5 MHz, $\left.\mathrm{CD}_{3} \mathrm{CN}, 298 \mathrm{~K}\right): \delta-79.3\left(\mathrm{~s}, \mathrm{CF}_{3}\right)$.

NMR studies of the catalytic hydrolysis of $\mathrm{Et}_{3} \mathrm{SiH}$ using 0.5 equiv of $\mathrm{H}_{2} \mathrm{O}$. In a Young cap NMR tube $0.01 \mathrm{mmol}$ of $\mathbf{1}(6.84 \mathrm{mg})$ was dissolved in $0.5 \mathrm{~mL}$ of dichlorometane- $d_{2}$ and treated with $1.0 \mathrm{mmol}$ of $\mathrm{Et}_{3} \mathrm{SiH}(161 \mu \mathrm{L})$ and $0.5 \mathrm{mmol}$ of water. Once hydrogen evolution ceases (after $1.5 \mathrm{~h}$ ) the sample was studied by ${ }^{1} \mathrm{H},{ }^{29} \mathrm{Si}\left\{{ }^{1} \mathrm{H}\right\}$, and ${ }^{13} \mathrm{C}\left\{{ }^{1} \mathrm{H}\right\}$ NMR spectroscopy. The NMR spectra evidenced the selective and quantitative formation of $\mathrm{Et}_{3} \mathrm{SiOSiEt}_{3} .{ }^{1} \mathrm{H}$ NMR $(300.13 \mathrm{MHz}$, $\mathrm{CD}_{2} \mathrm{Cl}_{2}, 298 \mathrm{~K}$ ): $\delta 0.96\left(\mathrm{t}, \mathrm{J}_{\mathrm{H}-\mathrm{H}}=7.9,18 \mathrm{H}, \mathrm{CH}_{3}\right), 0.56\left(\mathrm{q}, \mathrm{J}_{\mathrm{H}-\mathrm{H}}=7.9\right.$ $\left.\left.12 \mathrm{H}, \mathrm{CH}_{2}\right) .{ }^{13} \mathrm{C}^{1}{ }^{1} \mathrm{H}\right\}$-APT NMR $\left(75.5 \mathrm{MHz}, \mathrm{CD}_{2} \mathrm{Cl}_{2}, 298 \mathrm{~K}\right): \delta 7.3(\mathrm{~s}$ $\left.\left.\mathrm{CH}_{3}\right), 7.1\left(\mathrm{~s}, \mathrm{CH}_{2}\right) .{ }^{29} \mathrm{Si}^{1}{ }^{1} \mathrm{H}\right\}$ NMR $\left(79.5 \mathrm{MHz}, \mathrm{CD}_{2} \mathrm{Cl}_{2}, 298 \mathrm{~K}\right): \delta 8.9(\mathrm{~s}$, $\mathrm{Et}_{3} \mathrm{SiOSiEt}_{3}$.

NMR studies of the catalytic hydrolysis of $\mathrm{Et}_{3} \mathrm{SiH}$ using $\mathbf{5}$ equiv of $\mathbf{H}_{2} \mathrm{O}$. In a Young cap NMR tube $0.01 \mathrm{mmol}$ of $\mathbf{1}(6.84 \mathrm{mg})$ was dissolved in $0.5 \mathrm{~mL}$ of dichlorometane- $d_{2}$ and treated with $1.0 \mathrm{mmol}$ of $\mathrm{Et}_{3} \mathrm{SiH}(161 \mu \mathrm{L})$ and $5.0 \mathrm{mmol}$ of water. Once hydrogen evolution ceases (after $0.3 \mathrm{~h}$ ) the sample was studied by ${ }^{1} \mathrm{H},{ }^{29} \mathrm{Si}\left\{{ }^{1} \mathrm{H}\right\}$, and ${ }^{13} \mathrm{C}\left\{{ }^{1} \mathrm{H}\right\}$ NMR spectroscopy. The NMR spectra evidenced the selective and quantitative formation of $\mathrm{Et}_{3} \mathrm{SiOH} .{ }^{1} \mathrm{H}$ NMR $\left(300.13 \mathrm{MHz}, \mathrm{CD}_{2} \mathrm{Cl}_{2}\right.$, $298 \mathrm{~K}): \delta 3.06(\mathrm{br}, \mathrm{OH}), 1.02\left(\mathrm{t}, \mathrm{J}_{\mathrm{H}-\mathrm{H}}=7.9,9 \mathrm{H}, \mathrm{CH}_{3}\right), 0.63\left(\mathrm{q}, \mathrm{J}_{\mathrm{H}-\mathrm{H}}=\right.$ 7.9, $\left.\left.6 \mathrm{H}, \mathrm{CH}_{2}\right) .{ }^{13} \mathrm{C}^{1}{ }^{1} \mathrm{H}\right\}$-APT NMR $\left(75.5 \mathrm{MHz}, \mathrm{CD}_{2} \mathrm{Cl}_{2}, 298 \mathrm{~K}\right): \delta 7.1(\mathrm{~s}$ $\left.\left.\mathrm{CH}_{3}\right), 6.5\left(\mathrm{~s}, \mathrm{CH}_{2}\right) .{ }^{29} \mathrm{Si}{ }^{1} \mathrm{H}\right\}$ NMR $\left(79.5 \mathrm{MHz}, \mathrm{CD}_{2} \mathrm{Cl}_{2}, 298 \mathrm{~K}\right): \delta 18.3(\mathrm{~s}$, $\left.\mathrm{Et}_{3} \mathrm{SiOH}\right)$.
General Procedure for the Reactions of Hydrosilanes with Water Catalyzed by 1 . The reactions were carried out using a Man on the Moon series X102 kit (www.manonthemoontech.com) micro-reactor, with a total volume of $14.2 \mathrm{~mL}$, placed in a isothermal water bath at $298 \mathrm{~K}$.

In a typical procedure $1.0 \mathrm{mmol}$ of tertiary silanes $\left(\mathrm{Et}_{3} \mathrm{SiH} 161 \mu \mathrm{L}\right.$, $\mathrm{Me}_{2} \mathrm{PhSiH} 160 \mu \mathrm{L}, \mathrm{MePh}_{2} \mathrm{SiH} 204 \mu \mathrm{L}$ or $\left.\left(\mathrm{Me}_{3} \mathrm{SiO}\right)_{2} \mathrm{MeSiH} 280 \mu \mathrm{L}\right)$ or $0.5 \mathrm{mmol}$ of secondary silanes $\left(\mathrm{Et}_{2} \mathrm{SiH}_{2} 65 \mu \mathrm{L}\right.$ or $\mathrm{Me}_{2} \mathrm{HSiOSiHMe}_{2} 91$ $\mu \mathrm{L})$ was added to a solution of the catalyst precursors $1(0.01 \mathrm{mmol}$, $6.84 \mathrm{mg}$ with tertiary silanes or $0.005 \mathrm{mmol}, 3.42 \mathrm{mg}$ with secondary silanes) in $2 \mathrm{~mL}$ of the corresponding solvent (dichloromethane or tetrahydrofuran). The reactor was closed and the pressure measurement started. Once the pressure is stabilized, water (5.0 $\mathrm{mmol}$ with tertiary silanes or $2.5 \mathrm{mmol}$ with secondary silanes) was added with a syringe. Hydrogen evolution was measured till inner pressure in the micro-reactor remains constant. The amount of $\mathrm{H}_{2}$ $(\mathrm{mmol})$ produced during the reaction was calculated using the Ideal Gas Law, P.V = n.R.T. Once the reaction finished, the product was analyzed by ${ }^{1} \mathrm{H},{ }^{29} \mathrm{Si}\left\{{ }^{1} \mathrm{H}\right\},{ }^{29} \mathrm{Si}-{ }^{1} \mathrm{H} \quad \mathrm{HMQC}$ and ${ }^{13} \mathrm{C}\left\{{ }^{1} \mathrm{H}\right\} \quad \mathrm{NMR}$ spectroscopy (see supporting information).

\section{Computational details}

All DFT theoretical calculations have been carried out using the G09.D01 program package ${ }^{[20]}$. Full citation is given in supporting information. The B3LYP method ${ }^{[21]}$ has been employed including the D3 dispersion correction proposed by Grimme ${ }^{[22]}$ and the "ultrafine" grid. The def2-SVP basis set ${ }^{[23]}$ has been selected for all atoms for geometry optimizations and calculation of free energy corrections. Energies have been improved by single point calculations on the optimized structures using the def2-TZP basis set. Solvent effects have been including using the PCM continuum model for dichloromethane for all structures. ${ }^{[24]}$ In addition, two discrete water molecules have been included for the $\mathrm{Si}-\mathrm{H}$ bond activation process (structures from 5 to 7 ) in order to stabilize intermediate $\mathbf{7}$ by hydrogen bond.

\section{Acknowledgements}

The authors express their appreciation to the support from the MINECO/FEDER projects CONSOLIDER INGENIO-2010 MULTICAT CSD2009-00050, CTQ2011-27593 and CTQ201235665 and DGA/FSE (group E07) is also acknowledged. The coauthor V.P. thankfully acknowledges the resources from the supercomputer "Memento", and the technical expertise and assistance provided by the Institute for Biocomputation and Physics of Complex Systems (BIFI) - Universidad de Zaragoza.

\section{Keywords: Hydrogen generation • Iridium • Homogeneous} catalysis $\cdot$ Silanes Chemistry $\cdot$ Silanol

[1] a) U. Erbele, M. Felderhoff, F. Schueth, Angew. Chem. Int. Ed. 2009, 48 6608-6630. b) J. Graetz, Chem. Soc. Rev. 2009, 38, 73-82. c) R. F. Service, Science 2004, 305, 958-961.

[2] a) M. Roselló-Merino, J. López-Serrano, S. Conejero, J. Am. Chem. Soc 2013, 135, 10910-10913. b) R. Lan, J. T. S. Irvine, S. Tao, Int. J. Hydrogen Energy, 2012, 37, 1482-1494. c) W. Luo, P. G. Campbell, L. N. Zakharov, S.-Y. Liu, J. Am. Chem. Soc. 2011, 133, 19326-19329.

[3] M. Jeon, J. Han, J. Park, ACS Catal. 2012, 2, 1539-1549.

[4] a) M. Grasemann, G. Laurenczy, Energy Environ. Sci., 2012, 5, 81718181. b) J. F. Hull, Y. Himeda, W.-H. Wang, B. Hashiguchi, R. Periana, D. J. Szalda, J. T. Muckerman, E. Fujita, Nature Chem. 2012, 4, 383388. 
[5] a) D. Teichmann, W. Arlt, P. Wasserscheid, R. Freymann, Energy Environ. Sci. 2011, 4, 2767-2773. b) R. H. Crabtree, Energy Environ. Sci. 2008, 1, 134-138.

[6] a) M. Yu, H. Jing, X. Fu, Inorg. Chem. 2013, 52, 10741-10743. b) W Sattler, G. Parkin, J. Am. Chem. Soc. 2012, 134, 17462-17465. c) A. Krüger, M. Albrecht, Chem. Eur. J. 2012, 18, 652-658. d) Y. Kikukawa, Y Kuroda, K. Yamaguchi, N. Mizuno, Angew Chem. Int. Ed. 2012, 51, 2434-2437. e) A. Albright, R. E. Gawley, Tetrahedron Lett. 2011, 52 6130-6132. f) S. T. Tan, J. W. Kee, W. Y. Fan, Organometallics 2011 30, 4008-4013. g) T. Y. Lee, L. Dang, Z. Zhou, C. H. Yeung, Z. Lin, C. P. Lau, Eur. J. Inorg. Chem. 2010, 5675-5684. h) R. A. Corbin, E. A. Ison, M. M. Abu-Omar, Dalton. Trans. 2009, 2850-2855. i) E. A. Ison, R. A Corbin, M. M. Abu-Omar, J. Am. Chem. Soc. 2005, 127, 11938-11939. j) L. D. Field, B. A. Messerle, M. Rehr, L. P. Soler, T. W. Hambley, Organometallics 2003, 22, 2387-2395. k) U. Schubert, C. Lorenz, Inorg. Chem. 1997, 36, 1258-1259. I) E. Matarasso-Tchiroukhine, J. Chem. Soc., Chem. Commun. 1990, 681-682.

[7] a) W. Li, A. Wang, X. Yang, Y. Huang, T. Zhang, Chem. Commun. 2012 48, 9183-9185. b) J. John, E. Gravel, A. Hagège, H. Li, T. Gacoin, E. Doris, Angew. Chem. Int. Ed. 2011, 50, 7533-7536. c) N. Asao, Y. Ishikawa, N. Hatakeyama, Menggenbateer, Y. Yamamoto, M. Chen, W. Zhang, A. Inoue, Angew. Chem. Int. Ed. 2010, 49, 10093-10095. d) T. Mitsudome, S. Arita, H. Mori, T. Mizugaki, K. Jitsukawa, K. Kaneda, Angew. Chem. Int. Ed. 2008, 47, 7938-7940.

[8] a) M. A. Esteruelas, M. Oliván, L. A. Oro, J. I. Tolosa, J. Organomet. Chem. 1995, 487, 143-149. b) M. A. Esteruelas, O. Nürnberg, M. Oliván, L. A. Oro, H. Werner, Organometallics 1993, 12, 3264-3272. c) M. A. Esteruelas, J. Herrero, L. A. Oro, Organometallics 1993, 12, 2377-2379. d) M. A. Esteruelas, L. A. Oro, C. Valero, Organometallics 1991, 10, 462466. e) M. J. Fernández, L. A. Oro, B. R. Manzano, J. Mol. Catal. 1988, 45, 7-15. f) M. J. Fernández, M. A. Esteruelas, L. A. Oro, M. C. Apreda, C. Foces-Foces, F. H. Cano, Organometallics 1987, 6, 1751-1756. G) L. A. Oro, M. J. Fernández, M. A. Esteruelas, M. S. Jiménez, J. Mol. Catal. 1986, 37, 151-156.

[9] a) G. Lázaro, F. J. Fernández-Alvarez, M. Iglesias, C. Horna, E. Vispe, R. Sancho, F. J. Lahoz, M. Iglesias, J. J. Pérez-Torrente, L. A. Oro, Catal. Sci. Technol. 2014, 4, 62-70. b) G. Lázaro, M. Iglesias, F. J. FernándezAlvarez, P. J. Sanz Miguel, J. J. Pérez-Torrente, L. A. Oro, ChemCatChem 2013, 5, 1133-1141. c) M. Iglesias, M. Pérez-Nicolás, P J. Sanz Miguel, V. Polo, F. J. Fernández-Alvarez, J. J. Pérez-Torrente, L. A. Oro, Chem. Commun. 2012, 48, 9480-9482. d) M. V. Jimenez, J. J. Pérez-Torrente, M. I. Bartolomé, V. Gierz, F. J. Lahoz, L. A. Oro, Organometallics 2008, 27, 224-234. e) M. A. Esteruelas, F. J.
Fernández-Alvarez, A. M. López, E. Oñate, P. Ruiz-Sanchez, Organometallics 2006, 25, 5131-5138.

[10] R. Lalrempuia, M. Iglesias, V. Polo, P. J. Sanz Miguel, F. J. FernándezAlvarez, J. J. Pérez-Torrente, L. A. Oro, Angew. Chem. Int. Ed. 2012, 51, 12824-12827.

[11] NMR data for $\mathrm{R}_{3} \mathrm{SiOSiR}_{3}$ compounds: a) S. Park, D. Bézier, M. Brookhart, J. Am. Chem. Soc. 2012, 134, 11404-11407. b) A. Berkerfeld, W. E. Piers, M. Parvez, J. Am. Chem. Soc. 2010, 132, 10660-10661.

[12] NMR data for $\mathrm{R}_{3} \mathrm{SiOH}$ species: a) J. John, E. Gravel, A. Hagège, H. Li, T. Gacoin, E. Doris, Angew. Chem. Int. Ed. 2011, 50, 7533-7536. b) B. P. S Chauhan, A. Sarkar, M. Chauhan, A. Roka, Appl. Organometal. Chem. 2009, 23, 385-390. c) T. Tokuyasu, S. Kunikawa, A. Masuyama, M. Nojima, Org. Lett. 2002, 4, 3595-3598.

[13] For precedents of transition-metal complexes containing a metal- $\left(\eta^{3}\right.$ $\mathrm{HSiR}_{3} \mathrm{H}$ ) moiety see: T. Y. Lee, L. Dang, Z. Zhou, C. H. Yeung, Z. Lin, C. P. Lau, Eur. J. Inorg. Chem. 2010, 5675-5684.

[14] For precedents of $\mathrm{Ir}-\left(\eta^{1}-\mathrm{Si}-\mathrm{H}\right)$ interactions see: a) J. Yang, P. S. White, C. K. Schauer, M. Brookhart, Angew. Chem. Int. Ed. 2008, 47, 4141-4143. b) J. Yang, P. S. White, M. Brookhart, Organometallics 2010, 29, 6057 6064.

[15] M. Iglesias, P. J. Sanz Miguel, V. Polo, F. J. Fernández-Alvarez, J. J. Pérez-Torrente, L. A. Oro, Chem. Eur. J. 2013, 19, 17559-17566.

[16] a) D. M. Heinekey, A. Lledós, J. M. Lluch, Chem. Soc. Rev. 2004, 33, 175-182. b) G. J. Kubas, Catal. Lett. 2005, 104, 79-101. c) G. J. Kubas, Chem. Rev. 2007, 107, 4152-4205.

[17] M. A. Esteruelas, L. A. Oro, Chem. Rev. 1998, 98, 577-588.

[18] N. V. Belkova, E. S. Shubina, L. M. Epstein, Acc. Chem. Res. 2005, 38, 624-631.

[19] a) S. Chang, E. Scharrer, M. Brookhart, J. Mol. Catal. A: Chem. 1998, 130, 107-119. b) X.-L. Luo, R. H. Crabtree, J. Am. Chem. Soc. 1989, 111 2527-2535.

[20] Gaussian 09, Revision D.01, M. J. Frisch et al.

[21] a) C. Lee, W. Yang, W, R. G. Parr, Phys. Rev. B 1988, 37, 785-789. b) A. D. Becke, J. Chem. Phys. 1993, 98, 1372-1377. c) A. D. Becke, J. Chem. Phys. 1993, 98, 5648-5652.

[22] S. Grimme, J. Antony, S. Ehrlich, H. Krieg J. Chem. Phys. 2010, 132, 154104.

[23] F. Weigend, R. Ahlrichs, Phys. Chem. Chem. Phys. 2005, 7, 3297-3305.

[24] J. Tomasi, B. Mennucci, R. Cammi, Chem. Rev. 2005, 105, 2999-3094. 
